Original Research Article

\title{
Metrics of clonidine utilization in maintenance hemodialysis patients
}

\author{
Saritha M. ${ }^{1}$, Praveen Kumar K. ${ }^{2}$, Rama Mohan P. ${ }^{3 *}$
}

${ }^{1}$ Department of Pharmacology, East Point College of Medical Sciences and Research Centre, Bengaluru, Karnataka, India ${ }^{2}$ Department of Nephrology, ${ }^{3}$ Department of Pharmacology, Narayana Medical College, Nellore, Andhra Pradesh, India

Received: 29 April 2019

Accepted: 06 May 2019

\section{*Correspondence to:}

Dr. Rama Mohan Pathapati, Email: pill4ill@yahoo.co.in

Copyright: (C) the author(s), publisher and licensee Medip Academy. This is an openaccess article distributed under the terms of the Creative Commons Attribution NonCommercial License, which permits unrestricted noncommercial use, distribution, and reproduction in any medium, provided the original work is properly cited.

\begin{abstract}
Background: Clonidine is less frequently used by nephrologists. Data on clonidine prescribing trends in hemodialysis patients is sparse. We assessed the clonidine utilization metrics from the case records of patients undergoing maintenance hemodialysis.

Methods: In this retrospective chart review, we analysed the clinical records of hemodialysis patients using clonidine. We evaluated the frequency of clonidine use, mean dose of clonidine and percentage of patients receiving a particular dose. Additionally, we also correlated dose of clonidine with anti-hypertensive pill count.

Results: A total of 70 hemodialysis patients case records were screened. All $70 / 70(100 \%)$ of them were hypertensive. Only $25 / 70(35.74 \%)$ of patients were prescribed clonidine as an anti-hypertensive agent. The mean clonidine dose was $352 \pm 171 \mu \mathrm{g}$. Majority of patients $9 / 25(36 \%)$ received $400 \mu \mathrm{g}$ of clonidine. The dose of clonidine was prescribed in the order $400 \mu \mathrm{g}(36 \%)>200 \mu \mathrm{g}(32 \%)>600$ $\mu \mathrm{g}(16 \%)>100 \mu \mathrm{g}(8 \%)>300 \mu \mathrm{g}(4 \%)=700 \mu \mathrm{g}(4 \%)$. There was a statistically significant correlation in the strength of clonidine prescribed with increasing antihypertensive drugs $(\mathrm{p}<0.05)$.

Conclusions: In our study, we observed that $80 \%$ of our hemodialysis patients were non responders to either systolic blood pressure or diastolic blood pressure or both. Oral clonidine use was observed in $35.74 \%$ of our hemodialysis patients. There was a linear trend showing an increased dose of clonidine with an increase in the anti-hypertensive pill count.
\end{abstract}

Keywords: Anti-hypertensive pill count, Blood pressure response, Clonidine strength, Correlation, Dose

\section{INTRODUCTION}

Hypertension is associated with $90 \%$ of patients undergoing maintenance hemodialysis. ${ }^{1}$ All classes of antihypertensive drugs except diuretics can be prescribed in hemodialysis patients. ${ }^{2}$ For adequate BP control, the majority of dialysis patients need a combination of several antihypertensive drugs. Clonidine is a centrally acting antiadrenergic agent licensed for the treatment of hypertension. $^{3}$ It reduces peripheral nor epinephrine release by the stimulation of prejunctional inhibitory $\alpha 2$ adrenoceptors. ${ }^{4}$ In dialysis patients, clonidine is used as an add-on drug for the treatment of hypertension that is not properly controlled by drugs like Calcium channel blockers (CCB), Angiotensin converting enzyme inhibitors (ACEI) and Angiotensin receptor blockers (ARB). ${ }^{5}$ Drug utilization study allow us to understand the amount and rationale of drug use. Information regarding clonidine use is scanty. To this purpose, we assessed clonidine utilization metrics from the case records of patients undergoing maintenance hemodialysis.

\section{METHODS}

In this retrospective chart review, we analysed the clinical records of hemodialysis patients using clonidine. Case 
records were of both male and female patients between 1680 years were included. Records of patients who were undergoing peritoneal dialysis were excluded. This study was conducted between January to March 2019 at Narayana medical hospital. Demographic and biochemical data were collected. We also recorded a total number of antihypertensive drugs per prescription. We considered treatment as monotherapy if the patients are receiving only one active antihypertensive ingredient and as polytherapy in those taking one combination pill or two different pills. Hemodynamic responses were classified based on the therapeutic blood pressures into four groups. Group-A, SBP $<140$ and DBP $<90 \mathrm{mmHg}$, Group-B as SBP $\geq 140$ $\mathrm{mmHg}$ and DBP $\geq 90 \mathrm{mmHg}$, Group-C as SBP $\geq 140$ $\mathrm{mmHg}$ and DBP $<90 \mathrm{mmHg}$ and SBP $<140 \mathrm{mmHg}$ and DBP $\geq 90 \mathrm{mmHg}$ (Group-D). ${ }^{6}$ We evaluated the frequency of clonidine use, mean dose of clonidine and percentage of patients receiving a particular dose. Additionally, we also correlated dose of clonidine with anti-hypertensive pill burden.

Data was tabularized by using IBM SPSS Statistics for Windows, Version 21.0. Armonk, NY: IBM Corp. Results were presented as mean \pm standard deviation, numbers and percentages. Spearman correlation was used as an inferential statistical test. A p-value of less than 0.05 was considered significant.

\section{RESULTS}

A total of 70 hemodialysis patients' case records of were screened. All 70/70 (100\%) of them were hypertensive. Only 25/70 (35.74\%) of patients were prescribed clonidine as anti-hypertensive agent. The mean age of the patients was $46 \pm 12$ years. They were receiving hemodialysis therapy for duration of $2 \pm 2$ years.

The average serum creatinine and blood urea nitrogen were $10.29 \pm 6.03 \mathrm{mg} / \mathrm{dL}$ and $102 \pm 32 \mathrm{mg} / \mathrm{dL}$ respectively. The number of antihypertensives/Prescription was $3 \pm 1$. The mean clonidine dose was $352 \pm 171 \mu \mathrm{g}$ (Table 1). Blood pressure responses were as follows: $5 / 25(20 \%)$ are in Group-I, 16/25 (64\%) Group-II, 1/25 (4\%) Group-III and $3 / 25(12 \%)$ are in Group-IV. Calcium channel blockers were prescribed in 18/25 (72\%), 21/25 (84\%) beta blockers, 4/25(16\%) angiotensin converting enzyme inhibitors, and 2/25 (8\%) diuretics (Table 2).

\section{Table 1: Demographic and clinical parameters of hemodialysis patients.}

\begin{tabular}{|ll|}
\hline Parameter & Mean \pm SD \\
\hline Age (Years) & $46 \pm 12$ \\
\hline Serum creatinine $(\mathrm{mg} / \mathrm{dL})$ & $10.29 \pm 6.03$ \\
\hline Blood urea nitrogen $(\mathrm{mg} / \mathrm{dL})$ & $102 \pm 32$ \\
\hline Duration of hemodialysis (Years) & $2 \pm 2$ \\
\hline Antihypertensives/Prescription & $3 \pm 1$ \\
\hline Clonidine Dose $(\mu \mathrm{g})$ & $352 \pm 171$ \\
\hline $\begin{array}{l}\text { Clonidine dose with two drugs } \\
\text { antihypertensive regimen }(\mu \mathrm{g})\end{array}$ & $263 \pm 92$ \\
\hline $\begin{array}{l}\text { Clonidine dose with three drug } \\
\text { antihypertensive regimen }(\mu \mathrm{g})\end{array}$ & $379 \pm 197$ \\
\hline $\begin{array}{l}\text { Clonidine dose with four drug } \\
\text { antihypertensive regimen }(\mu \mathrm{g})\end{array}$ & $500 \pm 141$ \\
\hline $\begin{array}{l}\text { Clonidine dose with five drug } \\
\text { antihypertensive regimen }(\mu \mathrm{g})\end{array}$ & $400 \pm 0$ \\
\hline Systolic blood pressure $(\mathrm{mmHg})$ & $145 \pm 22(100-190)$ \\
\hline Diastolic blood pressure $(\mathrm{mmHg})$ & $87 \pm 6(70-90)$ \\
\hline
\end{tabular}

Table 2: Anti-hypertensive prescribing trends and blood pressure responses in hemodialysis patients.

\begin{tabular}{|lll|}
\hline Parameter & n and \% \\
\hline Female & 6 & $24 \%$ \\
\hline Male & 19 & $76 \%$ \\
\hline Calcium channel blockers & 18 & $72 \%$ \\
\hline Beta blockers & 21 & $84 \%$ \\
\hline $\begin{array}{l}\text { Angiotensin converting enzyme } \\
\text { inhibitors }\end{array}$ & 4 & $16 \%$ \\
\hline Diuretics & 2 & $8 \%$ \\
\hline $\begin{array}{l}\text { SBP }<140 \text { and DBP }<90 \mathrm{mmHg} \\
\text { (Group-I) }\end{array}$ & 5 & $20 \%$ \\
\hline $\begin{array}{l}\text { SBP } \geq 140 \mathrm{mmHg} \text { and DBP } \geq 90 \mathrm{mmHg} \\
(\text { Group-II) }\end{array}$ & 16 & $64 \%$ \\
\hline $\begin{array}{l}\text { SBP } \geq 140 \mathrm{mmHg} \text { and DBP }<90 \mathrm{mmHg} \\
(\text { Group-III) }\end{array}$ & 1 & $4 \%$ \\
\hline $\begin{array}{l}\text { SBP }<140 \mathrm{mmHg} \text { and DBP } \geq 90 \mathrm{mmHg} \\
(\text { Group-IV) }\end{array}$ & 3 & $12 \%$ \\
\hline
\end{tabular}

Table 3: Correlation between clonidine dose across anti-hypertensive regimens.

\begin{tabular}{|lllllllll|}
\hline \hline Clonidine & Hemodialysis patients & \multicolumn{2}{c}{ Anti HTN drug regimen } & & \multicolumn{2}{c|}{ Blood pressure $(\mathbf{m m H g})$} \\
\hline Dose & N & \% & Two & Three & Four & Five & Systolic & Diastolic \\
\hline $100 \mu \mathrm{g}$ & 2 & $8 \%$ & - & 2 & - & - & $135 \pm 7$ & $90 \pm 0$ \\
\hline $200 \mu \mathrm{g}$ & 8 & $32 \%$ & 5 & 3 & - & - & $143 \pm 13$ & $85 \pm 8$ \\
\hline $300 \mu \mathrm{g}$ & 1 & $4 \%$ & 1 & - & - & - & $150 \pm 0$ & $90 \pm 0$ \\
\hline $400 \mu \mathrm{g}$ & 9 & $36 \%$ & 2 & 5 & 1 & 1 & $148 \pm 30$ & $88 \pm 7$ \\
\hline $600 \mu \mathrm{g}$ & 4 & $16 \%$ & - & 3 & 1 & - & $153 \pm 25$ & $88 \pm 5$ \\
\hline $700 \mu \mathrm{g}$ & 1 & $4 \%$ & - & 1 & - & - & $130 \pm 0$ & $80 \pm 0$ \\
\hline
\end{tabular}

Spearman's Correlations between clonidine dose versus anti-hypertensive pill count $(r=0.39$ and $\mathrm{p}=0.048)$ 
Majority of patients $9 / 25(36 \%)$ received $400 \mu \mathrm{g}$ of clonidine. The dose of clonidine was prescribed in the order $400 \mu \mathrm{g}(36 \%)>200 \mu \mathrm{g}(32 \%)>600 \mu \mathrm{g}(16 \%)>100 \mu \mathrm{g}$ $(8 \%)>300 \mu \mathrm{g}(4 \%)=700 \mu \mathrm{g}(4 \%)$. There was a statistically significant correlation in strength of clonidine prescribed with increasing anti-hypertensive pill burden $(\mathrm{p}<0.05)$ (Table 3).

\section{DISCUSSION}

The majority of the patients of hemodialysis patients suffer from hypertension. Hypertension is a risk factor for adverse cardiovascular outcomes in patients undergoing hemodialysis. The Cause for hypertension in these patients could be due to high renin secretion, sympathetic overactivity, autonomic dysfunction increased endothelin expression, decreased nitric oxide availability, positive sodium balance and hypertonic dialysate. In this study, we observed that all the 70/70 (100\%) of patients undergoing maintenance hemodialysis were hypertensive and receiving antihypertensive medications. The average number of antihypertensives/Prescription was $3 \pm 1$. Despite poly drug antihypertensive therapy, we observed that $80 \%$ of our hemodialysis patients were nonresponders to either systolic blood pressure or diastolic blood pressure or both. All the blood pressure readings were taken before the start of dialysis and SBP $<140$ $\mathrm{mmHg}$ and $\mathrm{DBP}<90 \mathrm{~mm} \mathrm{Hg}$ was considered as target blood pressure for hemodialysis patients. ${ }^{7}$

In uraemia, increased sympathoadrenal activity contributes to chronically increase arterial pressure. ${ }^{8}$ Clonidine decreases sympathoadrenal activity by inhibiting $\alpha 2$-adrenoceptors on postganglionic parasympathetic neurons. ${ }^{9}$ In our study, oral clonidine was prescribed as add-on therapy in 25/70 (35.74\%) of patients. The reason for prescribing clonidine in our patients could be either severe hypertension or difficult to control hypertension. Other possible reasons include that the clonidine has a half-life 18-41 hour in ESRD patients and only $5 \%$ is removed by dialysis. ${ }^{10}$ Clonidine also reverses autonomic dysfunction in hemodialysis patients. ${ }^{11,12}$

One study has shown that $50.64 \%$ of patients were prescribed with clonidine. ${ }^{13}$ In another study, clonidine was prescribed in only $9.1 \%$ of hemodialysis patients. ${ }^{14}$ The variation in prescribing frequency could be either due to its high rate of adverse event profile or the experience of the nephrologists. The maximum prescribed dose was $700 \mu \mathrm{g}$. Literature has shown that the dosage is generally between 100 and $800 \mu \mathrm{g} /$ day (divided). ${ }^{15}$ In $32 \%$ of our study population, clonidine was the component of two antihypertensive drug regimens, $56 \%$ of three drugs, $8 \%$ of four drugs and $4 \%$ of five drug regimens. We also observed a statistically significant trend showing an increased dose of clonidine with an increase in the antihypertensive pill count.

\section{CONCLUSION}

In our study, we observed that $80 \%$ of our hemodialysis patients were non-responders to either systolic blood pressure or diastolic blood pressure or both. Oral clonidine use was observed in $35.74 \%$ of our hemodialysis patients. There was a linear trend showing an increased dose of clonidine with an increase in the antihypertensive pill count. More research is needed to understand prescribing trends of clonidine in hemodialysis.

Funding: No funding sources

Conflict of interest: None declared

Ethical approval: The study was approved by the Institutional Ethics Committee

\section{REFERENCES}

1. Agarwal R, Nissenson AR, Batlle D, Coyne DW, Trout JR, Warnock DG. Prevalence, treatment, and control of hypertension in chronic hemodialysis patients in the United States. Am J Med. 2003 Sep;115(4):291-7.

2. Horl MP, Horl WH. Drug therapy for hypertension in hemodialysis patients. Seminars in dialysis. 2004 JulAug;17(4):288-94.

3. Reis DJ, Piletz JE. The imidazoline receptor in control of blood pressure by clonidine and allied drugs. Am J Physiol. 1997;273(5):R1569-R71.

4. Wijeysundera DN, Naik JS, Beattie WS. Alpha-2 adrenergic agonists to prevent perioperative cardiovascular complications: a meta-analysis. The Am J Med. 2003 Jun 15;114(9):742-52.

5. Inrig JK. Antihypertensive agents in hemodialysis patients: a current perspective. Semin Dial. 2010 MayJun;23(3):290-7.

6. Aronow WS. Treatment of systemic hypertension. Am J Cardiovasc Dis. 2012;2(3):160-70.

7. Turner JM, Peixoto AJ. Blood pressure targets for hemodialysis patients. Kidney Int. 2017 Oct;92(4):816-823.

8. Izzo JL, Jr., Santarosa RP, Larrabee PS, Smith RJ, Kallay MC. Increased plasma norepinephrine and sympathetic nervous activity in essential hypertensive and uremic humans: effects of clonidine. J Cardiovasc Pharmacol. 1987;10(Suppl 12):S225-9.

9. Schlicker E, Feuerstein T. Human presynaptic receptors. Pharmacol Therapeutics. 2017 Apr;172:121.

10. Georgianos PI, Agarwal R. Pharmacotherapy of Hypertension in Chronic Dialysis Patients. Clin J Am Soc Nephrol. 2016 Nov 7;11(11):2062-75.

11. Gregorakos L, Thomaides T, Stratouli S, Sakayanni E. The use of clonidine in the management of autonomic overactivity in neuroleptic malignant syndrome. Clin Auton Res. 2000 Aug;10(4):193-6.

12. Shibao C, Gamboa A, Abraham R, Raj SR, Diedrich A, Black B, Robertson D, Biaggioni I. Clonidine for the treatment of supine hypertension and pressure 
natriuresis in autonomic failure. Hypertension. 2006 Mar;47(3):522-6.

13. Ahmad R, Habib A, Rehman S. Efficacy of various antihypertensive drugs in the treatment of hypertension in the patients of end-stage renal disease leading to hemodialysis: a retrospective study. Int $\mathbf{J}$ Adv Med. 2017;4:203-8.

14. Ribeiro H, Pereira S, Dias VP, Fernandes JC. PP.25.01: Clonidine the current effectiveness of an old drug in patients with chronic kidney disease. J Hypertension. 2015;33:e351.
15. Neil MJ. Clonidine: clinical pharmacology and therapeutic use in pain management. Current Clinical Pharmacol. 2011;6(4):280-7.

Cite this article as: Saritha M, Kumar PK, Rama Mohan P. Metrics of clonidine utilization in maintenance hemodialysis patients. Int $\mathrm{J}$ Basic Clin Pharmacol 2019;8:1229-32. 